\title{
Water Security of the Azerbaijan Republic: current situation and perspectives
}

\author{
IMANOV FARDA ${ }^{1}$, ADISHIRIN ALAKBAROV ${ }^{2}$, RUSTAM RAJABOV $^{\mathbf{1}} \&$ \\ ANAR NURIYEV ${ }^{1}$
}

1 Baku State University, Azerbaijan Republic

farda imanov@mail.ru

2 Azersu JSC, Azerbaijan Republic

One of the actual global problems of the XXI century is water provision for the population and various sectors of economy. Under the conditions of population growth and development of the economy all over the world, the usage of water resources has increased rapidly and water provision has worsened sharply in most regions and countries. As a result of climate change and global warming, a tendency of decrease of available water resources is observed. Aggravation of water problems directly affects food supply and ecological safety in certain regions. At present, water has become one of the decisive factors for the sustainable development of Azerbaijan Republic. Concerning improving water supply in the future, not only water demand management and more economical use are required; it is also important that modern education, research and practical design and construction works for increasing water resources management are accelerated. In this way, priorities for the country's water policy also include achieving good ecological status in rivers, lakes and water resources, and aiming at supply of water of international standards for the population and different sectors of the economy.

Water resources of the Azerbaijan Republic, their use and security are characterized by the figures in Table 1.

Table 1 Water resources and water abstraction of the Azerbaijan Republic.

\begin{tabular}{|c|c|c|c|}
\hline \multicolumn{2}{|c|}{ Type of water resources } & Water resources $\left(\mathrm{km}^{3}\right)$ & Water abstraction $\left(\mathrm{km}^{3}\right)$ \\
\hline \multirow{2}{*}{$\begin{array}{l}\text { Surface water } \\
\text { resources: }\end{array}$} & Local & 10.6 & 12.3 \\
\hline & Transboundary & 20.3 & \\
\hline \multicolumn{2}{|c|}{ Groundwater resources } & 4.40 & 1.70 \\
\hline \multicolumn{2}{|l|}{ Total } & 35.3 & 14.0 \\
\hline
\end{tabular}

In general, although an average local river water resource is approximately $10.6 \mathrm{~km}^{3}$, in recent times, on average approx. $12.27 \mathrm{~km}^{3}$ is abstracted annually. It is important that approx. $70 \%$ of the river resources (approx. $20.3 \mathrm{~km}^{3}$ ) originates in neighbouring countries, and is transported to the country by transboundary rivers. Moreover, those water flows into Azerbaijan highly polluted.

In general, the Azerbaijan Republic is considered as a country with limited water resources. The amount of water per capita is approx. $3253 \mathrm{~m}^{3} /$ year. If we take into account only local water resources, the figure is equal to approx. $1084 \mathrm{~m}^{3} /$ year. As a result of the regional impacts of climate change and global warming, there is a reduction of water resources in local Azerbaijani rivers. At the same time, increases in the repetition of floods and flooding and of the duration of drought periods are occurring.

The Azerbaijan Republic thus joined "The Convention on Protection and Usage of Transboundary Water Flows and İnternational Lakes" (17 March 1992, Helsinki), and ratified it on 14 March 2000. The Azerbaijan water policy is based on international water legislation in the field of protection and use of transboundary rivers.

Thus, it is considered as most important to have dialogue and discussion on water issues among all the river basins' countries and to maintain monitoring and information exchange on the quantity and quality of river water, and it is preferred to have cooperation based on bilateral agreements with the neighbouring countries. This makes possible just a partial solution of existing 
problems along the transboundary waters. The possibility of establishing a commission at a wider scale, such as reported as among the IHP UNESCO Committees of the Danube River basin, is being considered. And the proposed cooperation among the countries of Group II within the IHP UNESCO VIII phases from 2014 to 2021, is being carefully is considered.

Among others, the following measures will be considered, aimed at limiting of anthropogenic and/or climate change impacts on water resources regarded as the most reliable drinking water supply in Azerbaijan:

1 Construction of new reservoirs. There are about 135 water reservoir and the total capacity is approx. $21.5 \mathrm{~km}^{3}$; e.g. the Tachtakorpu Reservoir water volume is of $268.9 \times 10^{6} \mathrm{~m}^{3}$, built in 2013; the Shamkirchay Reservoir built in 2014 (approx. $160 \times 10^{6} \mathrm{~m}^{3}$ ).

2 The use of non-conventional water sources. Protection of the unique ecosystem of the Caspian Sea. Surface water collection ( $4.0 \mathrm{~km}^{3}$ per year), and rain harvesting for agriculture.

3 The distribution of the river flow for irrigation purposes. There are currently six main channels, but a series of new channels have been designed and will be built.

4 The application of modern technologies in the efficient use of water resources. Modern irrigation technologies have started to be used; in addition, treated wastewater should be reused. 